\title{
Analysis of thermal inactivation kinetics of membrane-bound polyphenol oxidases and peroxidases from Metroxylon sagu.
}

\begin{abstract}
Thermal inactivation kinetics for the purified membrane-bound polyphenol oxidases (mPPOs) and peroxidases (mPODs) isolated from Metroxylon sagu were analyzed. Each isoenzyme was treated at different time-temperature combinations in the range of $0-70 \mathrm{~min}$ and $20-70 \mathrm{C}$. Thermal inactivation rates constant $(\mathrm{k})$ at $70 \mathrm{C}$ for mPOD-I $(72.9 \times 10-3 / \mathrm{min})$ and $\mathrm{mPOD}-\mathrm{II}$ $(97.9 \times 10-3 / \mathrm{min})$ were lower than that of mPPO-I (379.7×10 -3/min) and mPPO-II $(138.1 \times 10$ $-3 / \mathrm{min})$. The activation energy for inactivation of $\mathrm{mPPO}-\mathrm{I}(32.94 \mathrm{kcal} / \mathrm{mol})$ and $\mathrm{mPPO}-\mathrm{II}$ $(40.34 \mathrm{kcal} / \mathrm{mol})$ was lower compared with mPOD-I $(45.77 \mathrm{kcal} / \mathrm{mol})$ and $\mathrm{mPOD}-\mathrm{II}$ $(40.62 \mathrm{kcal} / \mathrm{mol})$. The enthalpy values for mPOD-I $(45.08 \mathrm{kcal} / \mathrm{mol})$ and $\mathrm{mPOD}-\mathrm{II}$ $(39.94 \mathrm{kcal} / \mathrm{mol})$ were higher than those of mPPOs (mPPO-I, $32.26 \mathrm{kcal} / \mathrm{mol}$; $\mathrm{mPPO}-\mathrm{II}$, $39.66 \mathrm{kcal} / \mathrm{mol}$ ). This result implies that both $\mathrm{mPOD}-\mathrm{I}$ and $\mathrm{mPOD}-\mathrm{II}$ are more thermostable.
\end{abstract}

Keyword: Membrane bound enzymes; Polyphenol oxidases; Peroxidases. 